\title{
Response Sour Orange Citrus aurantium L. Seedlings in a Local Class Proline and Sodium Chloride in Avoid Damage to Salt Stress
}

\author{
Zeinalabiden Abdalhusin Handl* \\ College of Agriculture / Misan University Misan City - Republic of Iraq \\ *Corresponding author
}

\begin{abstract}
A B S T R A C T
Keywords

Citrus aurantium,

Proline and

Sodium Chloride,

Salt Stress.

Article Info

Accepted:

30 August 2016

Available Online:

10 October 2016

Experiment carried out during the agricultural season 2014-2015 in a private nursery in the Misan city to see the effect of Proline concentrations (0, 50 and 100) mmolec. $1^{-1}$ and Sodium chloride with water irrigation concentrations $(0,25$ and 50) mmolec. $1^{-1}$ and the interaction between them in Citrus aurantium L. seedlings in a local class to avoid salt stress in recipes vegetative growth, according to the design of randomized complete sectors RCBD global experiment and three replications, and the results can be summarized as follows: Characterized the treatment of proline concentration (100) mmolec. $1^{-1}$ in giving the highest in all the traits under study. Led treatment with sodium chloride concentration of irrigation water (50) mmolec. $1^{-1}$ to get lower rates in the number of leaves and plant height and thickness of the leg and mild weight of shoot dry weight of shoot dry weight of roots compared to the treatment comparison.
\end{abstract}

\section{Introduction}

The salinity of the soil and the salinity of irrigation water from the main problems hindering to increase the area under cultivation, especially in the arid and semiarid regions that depend irrigation principal means in agriculture, and that $20-30 \%$ of the land affected by salinity (FAO, 2002), attributed Ashraf et al., (2004) increasing the accumulation of salts in the soil to high temperatures and increased surface evaporation and poor irrigation and drainage systems management processes, which lead to high ground water level and move towards the surface of the soil salts characteristic poetic.
It mechanisms of salt tolerance is the ability to organize Alazmosze Osmoregulation where this organization maintains the bulge cells and increase cell juicy enough to resist external Alazmosze effort and the survival of the plant at high water potential (More negative) to allow him to absorb water from the soil more efficiently (Al-shahwany, 2006).

And facing the citrus cultivation in Iraq's many problems, especially in the cultivation in the central and southern regions areas of Iraq, including the high salinity of the soil and irrigation water. It classifies citrus as 
Salt sensitive plants, and vary the degree of vulnerability and according to the origins of the restaurant by the different types of citrus, are varied types in the extent to which the tissues to withstand the toxicity resulting from the accumulation of chloride ions or sodium or both Ben hayyim et al., (2007).

The sour orange (Citrus aurantium L.) seedlings belongs to the genus Citrus return to the family (Rutaceae) which grows in tropical and subtropical areas of India and is the original home of him Khan (2007), is the citrus of the important fruits for local consumption trees in Iraq as the number of fruit trees in Iraq 703,722 tree and the average yield per tree is $25.4 \mathrm{~kg} /$ tree, while the total output reached 17,838 tons (Directorate of Agricultural Statistics, 2014).

Many researchers noted that the foreign added to garrisons (condoms) osmosis, plant hormones, antioxidants, and other polyamines can create conditions suitable for the plant to work to reduce the damage caused by salinity Ashraf et al., (2004).

And it found that many of the garrison's osmosis stimulates bearing plant to salinity by encouraging the growth of vital processes associated with it. It is known that the accumulation of certain substances such as proline is a well-known mechanism used by the plant to cope with salt stress. Matysik et al., (2002)pointed out that works as an antioxidant, where he works to inhibit free radicals, it also urges the expression of proteins related to respond to stress saline Khedr et al., (2003), as well as it increases the activity of enzymes involved in the defense system antioxidant Hoque et al., (2008). He also noted Hamilton et al., (2001) that he works deduced from osmosis stress by regulating the pressure Alazmosze and work on the stability of many vital units operating in the cell.
Given the importance of studies in Iraq on salinity and reducing the harm to crops in general and citrus growth and seedlings Citrus aurantium local class in particular, so Plan aims research study Response Sour Orange Citrus aurantium L. seedlings in a local class Proline, sodium chloride in avoid Damage to salt stress.

\section{Materials and Methods}

Experiment carried out during the 20142015 agricultural season in a special nursery in Misan city to study the effect of spray proline concentrations $(0,50, \quad 100)$ mmolec. $1^{-1}$ and the addition of sodium chloride with irrigation water concentrations $(0,25,50)$ mmolec. $1^{-1}$ and the overlap between them in recipes vegetative growth of seedlings sour orange (Citrus aurantium.L) local class, with 108 seedlings were prepared six months old and homogeneous size as much as possible planted in pots capacity of $10 \mathrm{~kg}$ and the Loamy soil table 1 .

Sprayed seedlings so full wet early in the morning at a rate of two workshops where the sprayed proline at $15 / 3$ and two weeks later was added sodium chloride with irrigation water for the seedlings and after the passage of one month from the addition of sodium chloride splashed spray the second the same way as the first spray for proline as well as for sodium chloride. Applied experience followers of the design of randomized complete sectors (R.C.B.D) experiment a global, analyzed the results of the experiment using a statistical program (SAS 2000) and compared to the averages using less teams moral test (L.S.D) at the level of probability of 0.05 (Al-Rawi and Al-Ani, 1990). And studied the vegetative growth indicators for plants each module as follows: 


\section{The number of leaves / seedlings}

It has been calculating the number of leaves per seedlings beginning and end of the experiment, and the difference between them and extracted the average number of securities for each experimental unit.

\section{Plant height (cm)}

The measurement using a ruler starting from the surface of the soil pots up to the highest peak in the seedling at the beginning and end of the experiment, and the difference between the promised increase in height.

\section{Stem diameter $(\mathbf{m m})$}

It was measured by the thickness of a stem Seedling (Vernier calipers) beginning and end of the experiment, and the difference between the promised increases in diameter.

\section{Fresh weight of shoots (g)}

At the end of the experiment the plant was cut off from the surface of the soil level and for each transaction, and then weighed by a sensitive balance 200. Type HR Japanese origin.

\section{Dry weight of shoots (g)}

The same samples were measured fresh weight of shoots taken and dry the oven electrolysis at a temperature of $75^{\circ} \mathrm{C}$ for 48 hours and until proven weight and then weighed by a sensitive balance type 200HR Japanese origin.

\section{Dry weight of roots (g)}

The gouge plant roots with soil per unit experimental, then taken to a lab to wash with water carefully to remove suspended by the soil minutes and then the samples and placed in a ventilated room for a period of 24 hours for the purpose of dry and not rot and after that dried up well and put into bags and paper punch, to be transported beyond the samples to electric furnace for dried at a temperature of $75 \mathrm{M} \circ$ for 48 hours and until proven weight and then weighed by a sensitive balance type 200- HR Japanese origin.

\section{Results and Discussion}

The results (Table 2) that the spray proline has had a significant effect in the qualities of vegetative growth and noted the positive impact of proline in all traits were higher than spraying with 100 mmolec. $1^{-1}$ on the rest of concentrations to give a greater rate in the number of leaves (paper / seedlings), plant height $(\mathrm{cm})$, thickness stem Seedling $(\mathrm{mm})$, fresh weight of shoot ( $\mathrm{g}$ ), dry weight of shoots (g) and dry weight of roots (g), which amounted to 40.42 paper / seedling, $56.25 \mathrm{~cm}, 4.220 \mathrm{~mm}, 162.65 \mathrm{~g}, 66.23 \mathrm{~g}$ and $26.98 \mathrm{~g}$, respectively, compared to the treatment comparison, which gave 29.54 paper / seedlings, $41.77 \mathrm{~cm}, 3.840 \mathrm{~mm}$, $133.06 \mathrm{~g}, 44.32 \mathrm{~g}$ and $16.70 \mathrm{~g}$.

The reason has been attributed for this is that under tensile saline conditions plants produce some harmonious plants Azmoszea including proline and that work on the renewal of the rapid growth and keeps the organelles as well as working on water potential between the cytoplasm and the gap regulation and this is reflected positively on the virtual growth of the plant kaya et al., (2009) and this result agrees with the sentiments El-Hammady et al., (1999). 
Table.1 Analysis the soil used in of pot

\begin{tabular}{|c|c|c|c|c|c|c|c|c|c|}
\hline \multirow{2}{*}{ Soil tissues } & \multirow{2}{*}{ Organic matter } & \multirow{2}{*}{$\begin{array}{c}\mathrm{EC} \\
\end{array}$} & $\mathrm{Ds} / \mathrm{m}$ & \multirow{2}{*}{$\mathrm{Ph}$} & \multicolumn{5}{|c|}{ Ions dissolved (mille-equivalent / $\mathrm{L}$ ) } \\
\cline { 5 - 10 } & & & $\mathrm{Ca}++$ & $\mathrm{Mg}++$ & $\mathrm{Na}++$ & $\mathrm{Cl}$. & $\mathrm{So}_{4}$ & $\mathrm{HCo}_{3}$ \\
\hline Loamy soil & 1.5 grams $/ \mathrm{kg}$ & 1.2 & 7.2 & 4.6 & 3.3 & 1.8 & 5.6 & 3.4 & 2 \\
\hline
\end{tabular}

Table. 2 shows Response sour orangeseedlings to proline, sodium chloride in avoid Damage to salt stress

\begin{tabular}{|c|c|c|c|c|c|c|}
\hline $\begin{array}{l}\text { The name of the } \\
\text { treatment }\end{array}$ & $\begin{array}{c}\text { number of } \\
\text { leaves / } \\
\text { seedlings }\end{array}$ & $\begin{array}{l}\text { Plant } \\
\text { height } \\
(\mathrm{cm})\end{array}$ & $\begin{array}{c}\text { Stem } \\
\text { diameter } \\
(\mathrm{mm})\end{array}$ & $\begin{array}{l}\text { Fresh weight } \\
\text { of shoots (g) }\end{array}$ & $\begin{array}{l}\text { Dry weight } \\
\text { of shoots }(\mathrm{g})\end{array}$ & $\begin{array}{c}\text { Dry } \\
\text { weight of } \\
\text { roots }(\mathrm{g})\end{array}$ \\
\hline Comparison & 29.54 & 41.77 & 3.840 & 133.06 & 44.32 & 16.70 \\
\hline Nacl mmolec. $1^{-1}(25)$ & 18.39 & 33.75 & 3.217 & 123.39 & 34.02 & 11.85 \\
\hline Nacl mmolec. $1^{-1}(50)$ & 17.14 & 30.83 & 2.499 & 120.58 & 28.70 & 11.01 \\
\hline $\begin{array}{c}\text { Proline mmolec.1 } \\
{ }^{-} \\
\mathbf{( 5 0 )}\end{array}$ & 38.36 & 53.08 & 3.017 & 144.14 & 44.65 & 21.36 \\
\hline $\begin{array}{c}\begin{array}{c}\text { Proline mmolec. } 1^{-} \\
{ }_{1}(\mathbf{1 0 0})\end{array} \\
\end{array}$ & 40.42 & 56.25 & 4.220 & 162.65 & 66.23 & 26.98 \\
\hline $\begin{array}{c}{\text { Nacl mmolec. } 1^{-1}(25)}_{+} \\
{\text {Proline mmolec. } 1^{-}}_{1} \\
{ }_{(50)}\end{array}$ & 22.35 & 36.42 & 3.710 & 131.32 & 35.45 & 15.98 \\
\hline $\begin{array}{c}{\text { Nacl mmolec. } 1^{-1}(25)}_{+} \\
{\text {Proline mmolec. } 1^{-}}_{(100)}\end{array}$ & 29.60 & 40.33 & 4.167 & 138.46 & 40.85 & 19.61 \\
\hline $\begin{array}{c}\text { Nacl mmolec. } 1^{-1}(25) \\
+ \\
\text { Proline mmolec.1- } \\
1(50) \\
\end{array}$ & 21.14 & 35.44 & $\mathbf{3 . 3 3 3}$ & 119.97 & 32.25 & 14.02 \\
\hline $\begin{array}{c}\text { Nacl mmolec. } 1^{-1}(50) \\
+ \\
\text { Proline mmolec. }^{-} \\
{ }_{1}(100)\end{array}$ & 24.92 & 38.74 & 3.907 & 134.96 & 40.13 & 17.34 \\
\hline L.S.D. 0.05 & 2.27 & 2.081 & 0.3574 & 1.682 & 1.163 & 1.263 \\
\hline
\end{tabular}

The same table also shows that the concentration of sodium chloride 50 mmolec. $1^{-1}$ influential morally and gave the lowest rates in the studied traits number of leaves (paper / seedlings), plant height $(\mathrm{cm})$, thickness stem Seedling (mm), fresh weight shoot $(\mathrm{g})$, dry weight $(\mathrm{g})$ and dry weight of roots $(\mathrm{g})$, which amounted to 17.14 paper / seedlings,30.83 $\mathrm{cm}, 2.499 \quad \mathrm{~mm}, 120.58$ $\mathrm{g}, 28.70 \mathrm{~g}$ and $11.01 \mathrm{~g}$, respectively, 
compared to the treatment comparison, which gave 29.54 paper / seedlings and $41.77 \mathrm{~cm}$ and $3.840 \mathrm{~mm}$ and $133.06 \mathrm{~g}$, $44.32 \mathrm{~g}$ and $16.70 \mathrm{~g}$.

This may be attributed to the negative consequences occurring from increased salinity as it leads to an increase Osmotic pressure of soil solution exerting downward pressure so the amount of water available to the plant as reflected in a negative way on the vegetative growth of the plant, which in turn affects the amount of processed food, These findings are consistent with found Cerda et al., (1990) and is also consistent with the sentiments (Adnan Al-yassin, 2004) and that between the lead to reduce salinity holds citrus.

At last it is noted from Table 2 that the treatment of overlap between proline, sodium chloride and focus high for them has outperformed significantly in some of the traits compared to the treatment of comparison where excelled in the character of the thickness stem Seedling $3.907 \mathrm{~mm}$, the fresh weight of shoot $134.96 \mathrm{~g}$ dry weight of the roots of $17.34 \mathrm{~g}$.

\section{References}

Adnan Al -yassin. 2004. Influence of Salinity on Citrus: A Review Paper. $J$. Central European Agri., 5(4): 263269.

Al-Rawi, K.M., and Al-Ani, A.M. 1990. Design and Analysis of Agricultural Experiments. Al-Mosul University. Iraq.

Al-shahwany Ayyad Wigah Raof. 2006. Effect of Irrigation water salinitystress ongrowth, yield of Potatoand methods to reduce it. Doctoral thesis. College of Agriculture - University of Baghdad, Iraq.

Ashraf, M. and Foolad, M.R. 2007. Roles of glycine betaine and proline in improving plant abiotic stress resistance. Environ. Experiment Bot., 59(2): 206-216.

Ashraf, M., and Harris, P.J.C. 2004. Potential biochemical indicators of salinity tolerance in plant. Plant Sci., 166(1): 3-16.

Ben Hayyim, G. and Moore, G.A. 2007. Recent advances in breeding Citrus for drought and saline stress tolerance. In: Jenks, M.A., P.M. Hasegawa and S.M. Jain (eds.), Adv. Mol. Breeding toward Drought and Salt Tolerant Crops, pp: 627-642.

Cerda, A., M. Nieves and M. G. Guillen. 1990. Salt Tolerance of Lemon trees as affected by Rootstock. Irrigation Sci., 11(4): 245 -249.

Directorate of Agricultural Statistics. 2014. Ministry of Planning. Central Statistical Organization, Baghdad. Republic of Iraq.

El-Hammady, A.E., Wanas, W.H., El-Saidi, M.T. and Shahin, M.F.M. 1999. Impact of praline application on the growth of grape plantlets under salt stress in vivo Arab Univ. J. Agric Sci., 7: 191-202.

Food and Agriculture Organization (FAO) 2002. Crops and Drops.Making the best use of water for agriculture. Food and Agriculture Organization of the United Nations. Roma, pp. 26.

Hamilton, E.W., Heckathorn, S.A. 2001. Mitochondrial adaptation to $\mathrm{NaCl}$. Complex I is protected by antioxidants and small heat shock proteins, whereas complex II is protected by proline and betaine. Plant Physiol., 126: 12661274.

Hoque, M.A., Okuma, E., Nakamara, Y., Shimoishi, Y., Murata, Y. 2008. Proline and glycinebetaine enhance antioxidant defense and methylglyoxal detoxi fi cation systems and reduce 
$\mathrm{NaCl}$ inducedamage in cultured tobacco cells. J. Plant Physiol., 165: 813-824.

Kaya, C., Tuna, A.L. and Yokas, I. 2009. The role of plant hormones in plants hander salinity stress. In: Mshraf: M. Ozturk and H. R. Athar (Eds.). Salinity and water stress: Improving crop Efficiency. Springer Science and Business media B. V. Chapter, 5:4550.

Khan, I.A. 2007. Citrus Genetics, Breeding and Biotechnology. CAB International,
UK. 370 pages.

Khedr, A.H., Abbas, M.A., Wahid, A.A., Quick, W.P., Abogadallah, G.M. 2003. Proline induces the expression of salt-stress-responsive proteins and may improve the adaptation of Pancratium maritimum L. to saltstress. J. Exp. Bot., 54: 2553-2562.

Matysik, J., Alia, B., Mohanty, P. 2002. Molecular mechanisms of quenching of reactive oxygen species by proline under stress in plants. Curr. Sci., 82: 525-532.

\section{How to cite this article:}

Zeinalabiden Abdalhusin Handl. 2016. Response Sour Orange Citrus aurantium L. Seedlings in a Local Class Proline and Sodium Chloride in Avoid Damage to Salt Stress. Int.J.Curr.Microbiol.App.Sci. 5(10): 1066-1071. doi: http://dx.doi.org/10.20546/ijcmas.2016.510.112 